79 Aloia JF, Ross P, Vaswani A, Zanzi I, Cohn SH. Rate of bone loss in postmenopausal and steoporotic women. Am $\mathcal{F}$ Physiol (Endocrinol Metab 5 ) 1982;242:E82-6.

80 Chesnut CH III, Ivey JL, Gruber HE, et al. Stanozolol in postmenopausal osteoporosis: therapeutic efficacy and possible mechanisms of action Metabolism 1983;32:571-80.

81 Riggs BL, Hodgson SF, O'Fallon WM, et al. The effect of fluoride treatment on fracture rate in osteoporotic women. $N$ Engl $\mathcal{F}$ Med (in press).

$82 \mathrm{Ott}$ SM, Chesnut $\mathrm{CH}$ III. Calcitriol treatment is not effective in postmenopausal osteoporosis. Ann Intern Med 1989;110:267-74.

83 Riggs BL, Seeman E, Hodgson SF, Taves DR, O'Fallon WM. Effect of the fluoride/calcium regimen on vertebral fracture occurring in postmenopausal fluoride/calcium regimen on vertebral fracture
osteoporosis. $N$ Engl f Med 1982;306:446-50.
84 Nordin BEC, Horsman A, Crilly AG, Marshall DH, Simpson M. Treatment of spinal osteoporosis in postmenopausal women. Br Med f 1980;280:451-4.

85 Need AG, Chatterton BE, Walker CJ, Steurer TA, Horowitz M, Nordin BEC Comparison of calcium, calcitriol, ovarian hormones and nandrolone in the treatment of osteoporosis. Maturitas 1986;8:275-80.

86 Nordin BEC, Need AG, Chatterton BE, Horowitz M, Morris HA. The relative contributions of age and years since menopause to postmenopausal bone loss. F Clin Endocrinol Metab 1990;70:83-8.

87 Nordin BEC, Morris HA. The calcium deficiency model for osteoporosis. Nutr Rev 1989;47:65-72.

(Accepted 19 January 1990)

\title{
What does community care mean now?
}

\section{Trish Groves}

Relatives and friends provide the bulk of community care for about two million chronically ill and disabled people under 65 in England and Wales.' Nobody knows how many care for people with mental illness nor how many find that job difficult, though the experiences of voluntary organisations such as the National Schizophrenia Fellowship give some idea. The fellowship has over 6000 members and 150 local groups and in 1988 received more than 5000 appeals for help and advice (table I) from schizophrenic people and their relatives. ${ }^{2}$

One of the hardest things about caring for mentally

TABLE I-Number of calls to the National Schizophrenia Fellowship in 1988 according to topics of concern

\begin{tabular}{lr}
\hline Deficiencies identified & $\begin{array}{c}\text { No of } \\
\text { calls }\end{array}$ \\
\hline General advice & 3066 \\
Community care and treatment & 678 \\
Family support & 546 \\
Accommodation & 315 \\
Social services & 282 \\
Obtaining benefits & 198 \\
Legal inquiries & 153 \\
Hospital care & 84 \\
\hline Total & 5322
\end{tabular}

Br Med f 1990;300:1060-2

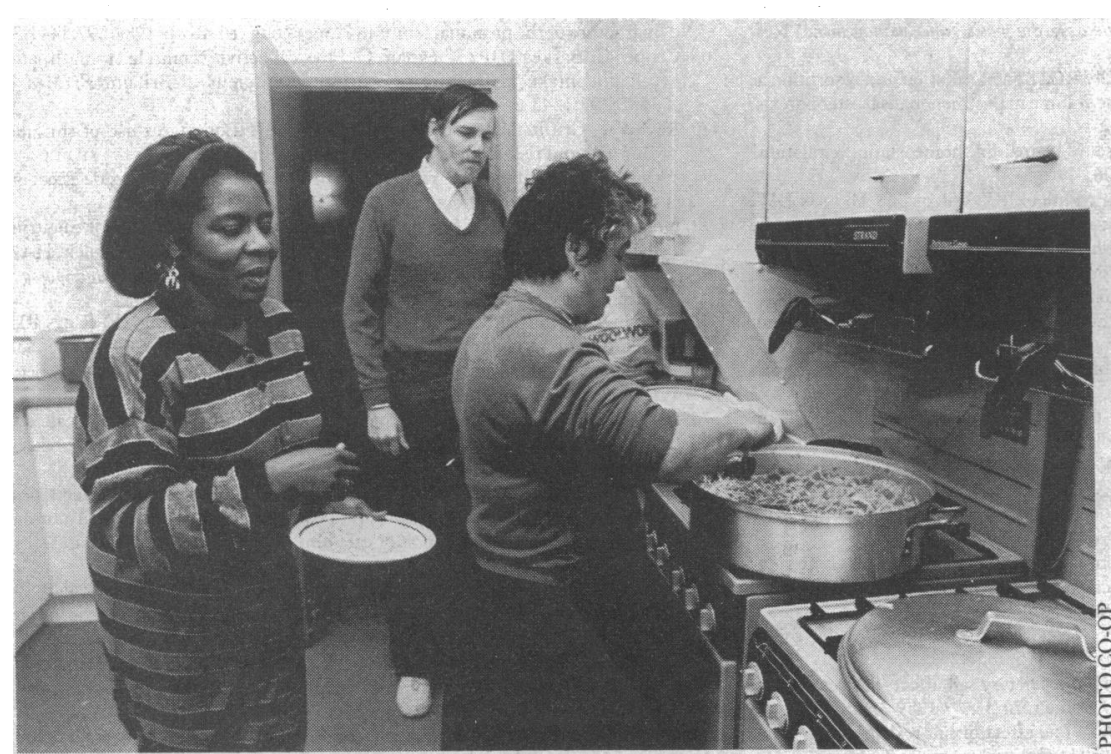

Hostels can be happy and healthy places to live. But how many are there, and how many more do we need?
"He has spent half of the 13 years of his illness in and out of hospital and prison for minor offences, set fire to his mother's house, and attempted suicide three times in one year. The third time, the hospital tried to send him home on a bus with his pills. He is seen once a week by a psychiatric nurse who administers his antipsychotic injections. The brief visit is the only support he and his mother receive. He refuses to go to a day centre because he thinks that people are staring at him.

'He was discharged into a community care system that turned out to be me,' says his mother."-One schizophrenic patient's story, reported in The Times on 12 July 1989.

ill relatives and friends at home is that it is often a forced choice (box). A young patient with chronic schizophrenia may have only two other options on leaving hospital-a hostel or bed and breakfast accommodation. Middle aged patients may have even less choice if their parents are old and their siblings are too busy with careers and children. Even when living at home is the first choice, it may not be good for patients or relatives: in schizophrenia it can worsen prognosis ${ }^{3}$ and can hasten relapse if it engenders an emotionally charged atmosphere. ${ }^{4}$ Relatives may become anxious and depressed and shunned by embarrassed friends, so that they have to turn to strangers for help.

The government recognises these stresses and expects social services authorities to arrange support for these informal carers. But it also states that its first aim in reorganising community care is to enable more ill and disabled people to live at home whenever possible. ${ }^{1}$ For many severely mentally ill people living at home will not be possible unless they and their carers can get help during crises as well as in the long term. This means that there must be properly funded emergency clinics, out of hours social work teams, respite care beds, and special family therapy ${ }^{67}$ in addition to less formal support. And for those who cannot cope alone or live with relatives there must be suitable accommodation.

\section{NHS provision}

The exact number of hospital beds for people with long term mental illness is not known. Perhaps this deficiency is predictable because data on admissions, bed use, and discharges are notoriously inaccurate in 
all health specialties. Some are based on number of beds and others on number of patients occupying them, and mental hosptial data do not always distinguish between acute, long stay, and psychogeriatric beds.

When the National Schizophrenia Fellowship tried to find out the number of beds remaining and the number due to close it found many inconsistencies in government statistics. But it seems to have had more luck than the opposition health spokesman (box). The fellowship established that 30 mental hospitals closed between 1980 and 1989 and that a further 38, with 12500 beds, were earmarked for closure before 1995 . Presumably these hospitals have now shelved their plans because the government has halted the closure programme. It began in 1954 when the number of psychiatric beds peaked at 148000 and it aimed at reducing beds to a target of 47900: about 64000 now remain. ${ }^{8}$

Accurate data on outpatient services are just as hard to find. The Department of Health cannot quantify hospital day care after 1986, when there were 18660 places for mentally ill adults including those who were elderly and demented.

Nationwide surveys by psychiatrists suggest yawning gaps in some parts of the country. ${ }^{910}$ Kingdon requested copies of strategic plans for mental health made in 1984 from England's 192 district health authorities. ${ }^{10}$ Of the 127 districts that responded a half had no mental hospitals and a third were planning to close them. Rehabilitation teams were mentioned by only a third. Most failed to mention plans for new long stay patients, although nine described entirely community based care for them and 11 mentioned intensively staffed hostels on hospital sites. Interestingly, the Department of Health is aware of only three hospital hostels, even though it has been advocating them since 1975. ${ }^{11}$ The survey showed a more encouraging picture for day care: day hospitals were provided by half of the districts and planned by the rest, and although there were few community mental health centres, two thirds were planning them.

Uneven distribution of psychiatric services might reflect different rates at which old asylums are closed,

TABLE II-Residential provision for mentally ill adults in England in 1987

\begin{tabular}{|c|c|c|c|c|c|}
\hline & \multicolumn{2}{|c|}{$\begin{array}{l}\text { Local authority } \\
\text { homes }\end{array}$} & \multicolumn{2}{|c|}{ Registered homes } & \multirow[b]{2}{*}{ Total } \\
\hline & Staffed & Unstaffed & Voluntary & Private & \\
\hline $\begin{array}{l}\text { No of homes } \\
\text { No of places }\end{array}$ & $\begin{array}{r}166 \\
2676\end{array}$ & $\begin{array}{r}476 \\
1957\end{array}$ & $\begin{array}{r}165 \\
2103\end{array}$ & $\begin{array}{r}208 \\
2432\end{array}$ & $\begin{array}{l}1015 \\
9168\end{array}$ \\
\hline
\end{tabular}

TABLE III-Regional summary of local authority provision for mentally ill people in England in March 1987. Figures are numbers of places/100000 population aged $\geqslant 16$ years

\begin{tabular}{|c|c|c|c|c|c|}
\hline \multirow[b]{2}{*}{ Region } & \multirow{2}{*}{$\begin{array}{l}\text { Local authority } \\
\text { day centres for } \\
\text { the mentally ill }\end{array}$} & \multicolumn{2}{|c|}{ Local authority homes } & \multicolumn{2}{|c|}{ Registered homes } \\
\hline & & Staffed & Unstaffed & Voluntary & Private \\
\hline England & $15 \cdot 6$ & $7 \cdot 1$ & $5 \cdot 2$ & $5 \cdot 6$ & $6 \cdot 5$ \\
\hline Northern & $15 \cdot 3$ & $8 \cdot 1$ & $5 \cdot 6$ & $2 \cdot 2$ & $3 \cdot 8$ \\
\hline Yorks/Humberside & $18 \cdot 5$ & $9 \cdot 8$ & $4 \cdot 4$ & $1 \cdot 7$ & $8 \cdot 9$ \\
\hline North Western & $14 \cdot 4$ & $9 \cdot 2$ & $4 \cdot 4$ & $4 \cdot 1$ & $4 \cdot 7$ \\
\hline West Midlands & $20 \cdot 7$ & $9 \cdot 1$ & $4 \cdot 5$ & $5 \cdot 8$ & $4 \cdot 6$ \\
\hline East Midlands & $15 \cdot 3$ & $4 \cdot 9$ & $7 \cdot 1$ & $0 \cdot 8$ & $11 \cdot 6$ \\
\hline Thames/Anglian & $1 \cdot 6$ & $3 \cdot 0$ & $4 \cdot 4$ & $4 \cdot 4$ & $5 \cdot 5$ \\
\hline Inner London & $53 \cdot 6$ & $17 \cdot 8$ & $3 \cdot 4$ & $13 \cdot 9$ & $1 \cdot 7$ \\
\hline Outer London & $27 \cdot 3$ & $11 \cdot 5$ & $7 \cdot 6$ & $11 \cdot 1$ & $1 \cdot 4$ \\
\hline Southern & $8 \cdot 9$ & $2 \cdot 9$ & $5 \cdot 3$ & $10 \cdot 0$ & $11 \cdot 0$ \\
\hline South Western & $6 \cdot 9$ & $1 \cdot 5$ & $5 \cdot 9$ & $2 \cdot 7$ & $8 \cdot 2$ \\
\hline
\end{tabular}

"The closure programme has been so rapid that ministers seem to have had difficulty keeping abreast of it. Last year I tabled a parliamentary question inviting ministers to list the mental health hospitals for which there were no closure plans... it included four which had already closed at the time of the answer and two others which had closed during the time it took to carry out the survey."-Robin Cook, opposition health spokesman, speaking in parliament on 26 June 1989.

with those districts that have relatively few beds having better community care. Sadly, this does not seem to be the case-the Royal College of Psychiatrists says that most districts with high numbers of beds also have more community nurses and more day places. ${ }^{12}$ The college and other mental health organisation $s^{13}$ have produced detailed blueprints for ideal psychiatric services but have not estimated how many long stay beds will be needed in future. ${ }^{13}$

\section{Community care provided by social services}

The Department of Health derives all of its data on residential care for mentally ill people, even the care provided by voluntary organisations, from England's l09 social services departments (table II). Unfortunately the data imply that there are many private sector homes for chronically mentally ill people when in fact this holds true only for those aged over 65 . In the past year or two a few small private places have opened for younger people, usually as lodgings in nurses' own homes.

The same problem of age mixing distorts the data on social services day centres and makes it impossible to tell whether the services offered in old asylums are being replaced adequately. There were 163 centres with 5889 places in 1987 , but it is not clear how many were used by recently demented elderly patients and how many by adults who would otherwise have been long term psychiatric inpatients. And, like health services, social services are unevenly distributed around the country (table III). The Scottish Association for Mental Health says that the situation is particularly bad north of the border. The association estimates that a third of Scotland's 13000 mental hospital patients could be discharged if there were adequate facilities in the community; Scotland has only one local authority day centre for mentally ill people. ${ }^{14}$

\section{Voluntary organisations}

Caring for People gives the impression that there is a wide range of voluntary services for people with mental illness and that it just needs coordinating.' Certainly there are many different organisations, ${ }^{15}$ but not all provide services that equate to the long term residential care previously offered by the NHS.

One of the largest providers of residential care and psychiatric rehabilitation is the Richmond Fellowship. It has nearly 30 houses nation wide, run by its own trained staff, that offer both temporary and long term care for people with severe mental illness. The houses are run as therapeutic communities in which residents are given as much personal and communal responsibility as possible. The Richmond Fellowship also has a range of group homes (supervised but unstaffed) in 11 cities and several special units for children and adolescents, families, and misusers of alcohol and drugs. In total it houses nearly 500 residents.

MIND (the National Association for Mental Health) 
is another large provider. Unlike Richmond Fellowship houses MIND hostels are not run by one central office-its local groups (nearly 200 in total) are affiliated, or effectively franchised, and do not rely on the organisation's central headquarters in London for administration. Such local control probably has many advantages, but one big disadvantage is that the central office has no data on the number, size, or distribution of MIND hostels. Groups vary around the country: in the next article I will look at one in the north of England that does not offer accommodation but contributes a range of other services such as day centres and a befriending scheme.

There are other smaller, less publicised organisations, such as the Psychiatric Rehabilitation Association and the Mental After Care Association, that provide hostels and day centres. These voluntary sector services develop in response to local need, often intending only to fill temporary gaps in statutory services. They make do with an eclectic mix of staff and with funding sources that include central government, health authorities, social services departments, housing associations, charities, and residents' social security benefits. On the one hand, case managers could use the new community care structure to encourage these organisations and to rationalise their administrative complexities. On the other hand, however, the proposed competitive market could squash small organisations in favour of bigger and more established groups, particularly if groups are expected to plan ahead and provide services for many years. And contracts between social services departments and the voluntary sector will probably concentrate on the most concrete schemes (accommodation and day care) at the expense of less visible, more innovative ideas such as user participation ${ }^{16}$ and advocacy. While the new policy may reasonably divert public money towards services that have proven track records, it may unreasonably narrow consumer choice and impoverish community care.

\section{The national picture}

To understand what the new proposals for community care might mean we need more information about existing services. It would be useful to draw a map of Britain and mark on it the areas that still lack adequate community care for people with long term mental illness. With current knowledge it is impossible to do so. The Department of Health had well over a year to consider its response to the Griffiths report ${ }^{17}$ but did not gather together a clear national picture of the services it was proposing to organise. Last autumn, when its proposals were already decided, the Department commissioned such a survey. Let us hope that it finds enough care in the community with which to work.

1 Secretaries of State for Health, Social Security, Wales, and Scotland. Caring for people: community care in the next decade and beyond. London: HMSO, 1989. people: community care in the next decade and beyond. London: HMSO, 1989. NSF, 1989.

3 Brown GW, Carstairs GM, Topping GG. Post-hospital adjustment of chronic mental patients. Lancet 1958;ii:685-9.

4 Leff JP, Vaughn CE. Expressed emotion in families. New York: Guilford Press, 1985.

5 Creer C. Social work with patients and their families. In: Wing J, ed. Schizophrenia: towards a new synthesis. London: Academic Press, 1978

6 Falloon IRH, Boyd JL, McGill CW, et al. Family management in the prevention of exacerbations of schizophrenia: a controlled longitudinal study. Arch Gen Psychiatry 1985;42:887-96.

7 Waldron G. Crisis intervention: is it effective? Br $\mathcal{F}$ Hosp Med 1984;31:283.

8 Thornicroft G, Bebbington P. Deinstitutionalisation: from hospital closure to service development. Br $\mathcal{F}$ Psychiatry 1990;155:739-53.

9 Thornicroft G. Progress towards DHSS targets for community care. $\mathrm{Br} \mathcal{F}$ Psychiatry 1988;153:257-8.

10 Kingdon D. Mental health services: results of a survey of English district plans. Psychiatric Bulletin 1989;13:77-8.

11 Department of Health and Social Security. Better services for the mentally ill. London: HMSO, 1975.

12 Working party of the section for social and community psychiatry of the Royal College of Psychiatrists. Psychiatric beds and resources: factors influencing bed use and service planning. London: Gaskell, 1988.

13 MIND (National Association for Mental Health). Common concern. London: MIND, 1983.

14 McKenzie E. Concern at shortage of services for mentally ill. Scotsman 1990 Feb 3:7.

15 Gloag D. Rehabilitation in psychiatric conditions: 2-psychological approaches and support, the family, and activities. $\mathrm{Br} \operatorname{Med} \mathcal{F}$ 1985;290:1062.

16 Anderson J. Patient power in mental health. Br Med f 1989;299: 1477-8. 17 Griffiths R. Community care: agenda for action. London: HMSO, 1988.

\section{BOOKS RECEIVED}

\section{History of medicine \\ St Andrew's Hospital Northampton: The First 150 Years (1838-1988). A Foss, $\mathrm{K}$ Trick. (Pp viii +312 ; figs; $£ 14.95$.) Cambridge: Granta Editions, 1989. ISBN 0-906782-44-9. \\ Neuroimmunology}

Neuroimmune Networks: Physiology and Diseases. Ed E J Goetzl, $\mathrm{N} \mathrm{H}$ and Diseases. Ed E J Goetzl, $\mathrm{N}$ H Spector. (Pp xv+290; figs; $\$ 69.50$.)
New York: Liss, 1989. Distributed by New York: Liss, 1989. Distributed by
John Wiley and Sons. ISBN 0-8451John

Neurology

Central Cholinergic Synaptic Transmission. Ed M Frotscher, U Misgeld. (Pp x + 323; figs; Sw frs 138.) Basel: Birkäuser, 1989. ISBN 3-76432267-5.

Disorders of Movement: Clinical, Pharmacological and Physiological Aspects. Ed N P Quinn, P G Jenner. (Pp xxiy 567; figs; 600 ) London: (Pp xxiv + 567; figs; 160.) London: Academic Press, 1989. Distributed by Harcourt Brace Jo

Essentials of Clinical Neurology. C $\mathrm{H}$ Gunderson. (Pp xiv +550; figs; \$69.) New York: Raven Press, 1989. ISBN 0-88167-564-4.

Frontiers of Neuroscience. Vol 7. "Assessment of the Behavioral Conse"Assessment of the Behavioral ConseLezak. Series editors I Bodis-Wollner, E A Zimmerman. (Pp xiii +224; figs; E A Zimmerman. (Pp xiii +224; figs;
\$79.50.) New York: Liss, 1989. Dis$\$ 79.50$.) New York: Liss, 1989. Dis-
tributed by John Wiley and Sons. tributed by John Wi
ISBN 0-471-51623-6.
Illustrated Guide to the Central Nervous System. K Sugiura, G A Robinson, D G Stuart. (Pp x + 160; figs; $£ 19.25$ paperback.) St Louis: Ishiyaku Europaperback.) St Louis: Ishiyaku EuroMRI Atlas of the Brain. W G Bradley, $\mathrm{G}$ Bydder. (Pp x+354; figs; 279.95 .) London: Dunitz, 1989. ISBN 0-948269-46-4.

The Pediatric Neurosurgical Patient: a Cooperative Approach. Ed L P Ivan. ( $\mathrm{Pp} \mathrm{xv}+323$; figs; paperback, price (Pp $x v+323$; figs; paperback, price
not stated.) Missouri: Green, 1989 . not stated.) Missour:
ISBN 0-87527-352-1.

Textbook of Head Injury. D P Becker, S K Gudeman. (Pp xv + 553; figs; £100.) Philadelphia: Saunders, 1989 Distributed by Harcourt Brace Jovanovich. ISBN 0-7216-1614-3.

Nutrition

Current Topics in Nutrition and Disease. Vol 22. "New Protective Roles for Selected Nutrients." Ed G A Spiller, J Scala. Series editors A A Albanese, D Kritchevsky. (Pp xii +357; figs; \$95.) New York: Liss, 1989. Distribut \$95. New York: Liss, 1989. Distributed by 1621-5.

\section{Oncology} Benign Disorders and Diseases of the
Breast: Concepts and Clinical ManageBreast: Concepts and Clinical Manage-
ment. L E Hughes, R E Mansel, D J T mebster. (Pp x +212; figs and colour Webster. (Pp x+212; figs and colour
plates; £39.50.) London: Baillière plates; $\{39.50$.) London: Baillière
Tindall, 1989. Distributed by HarTindall, 1989. Distributed by $\mathrm{Har}-$
court Brace Jovanovich. ISBN $0-7020-$ court Brace
Cancer Biology and Management: an Introduction. C J Williams. (Pp x +441 ; figs; $£ 19.50$ paperback.) Chiches Wiley, 1990. ISBN 0-471-91781-8.

The Cancer Series. "Control of Pain and Other Symptoms in Cancer Patients." T I Tønnessen. Series editor J V Johannessen. (Pp xiv + 196; figs; £30.) New York: Hemisphere, 1989. ISBN 0-89116-868-0.

Ethical Dilemmas in Cancer Care. Ed B A Stoll. (Pp xii+134; $\{25$. London: Macmillan, 1989. ISBN 0-333-48734-6.

Fight Cancer. K Sikora, H Thomas. (Pp 176; figs; $\{4.99$ paperback. London: BBC Books, 1989. ISBN 0-563-20863-5.

Head and Neck Oncology: Clinical Management. Ed A R Kagan, J Miles. Management. Ed A R Kagan, J Miles.
(Pp vi +176 ; figs; £33.51.) New York: Pergamon, 1989. ISBN 0-08York: Per

Ovarian Cancer: Biological and Therapeutic Challenges. Ed F Sharp, W P Mason, R E Leake. (Pp xv+480; figs; £65.) London: Chapman and Hall Medical, 1990. ISBN 0-412-35190-0. Social Dilemmas in Cancer Prevention. Ed B A Stoll. (Pp xii $+140 ; £ 25$. London: Macmillan, 1989. ISBN 0-333-48733-8.

\section{Ophthalmology}

Atlas of Ocular Motility. L B Nelson, R A Catalano. (Pp xii +228 ; figs; 660.75.) Philadelphia: Saunders, 1989 Distributed by Harcourt Brace Jovanovich. ISBN 0-7216-2628-9.
Paediatrics

$A B C$ of Child Abuse. Articles published in the British Medical fournal. Ed $\mathrm{R}$ Meadow. ( $\mathrm{Pp}$ viii +59 ; figs and colour plates; $£ 9.95$ overseas $£ 12.50$ paperback, including postage, airmail overseas. BMA members $\$ 8.95$, overseas $\$ 11.50$ including postage.) London: British Medical fournal, 1989. In North America available from the American College of Physicians, PO Box 7777-R-0270, Philadelphia, PA 19175, USA. ISBN 0-7279-0258-X. Child and Adolescent Development: Clinical Implications. V C Vaughan, III, I F Litt. (Pp viii + 362; figs; $\$ 32$.) Philadelphia: Saunders, 1990. Distributed by Harcourt Brace Jovanovich. ISBN 0-7216-1394-2.

Clinical Pediatric Endocrinology. S A Kaplan. (Pp $x+470$; figs; $\{46.50$.) Kaplan (Pp $\mathrm{x}+470$, fgs, 246.50.) Philadelphia: Saunders, 1990. Distributed by Harcourt B

Help Your Child to Sleep: a Handbook for Parents and Health Visitors. R Pound. (Pp 64; figs; £2.95.) Bath: Millstream, 1989. ISBN 0-94897517-2.

Pharmacology-clinical

Clinical Pharmacology. Vol 15. "Cardiovascular Function of Peripheral Dopamine Receptors." Ed J P Hiebl. Series editor M Weiner. (Pp xvii 359 ; figs; $\$ 150$.) New York: Dekker, 1990. ISBN 0-8247-8100-7. Frontiers in Pharmacology and Therapeutics. "Platelet Activating Factor in
Human Disease." Ed P J Barnes, C P Page, P M Henson. (Pp xv + 335; figs; £49.50.) Oxford: Blackwell Scientific, 1989. ISBN 0-632-02684-7.

House Officer's Pocket Drug Reference. Ed K Law, R Foltz. (Pp xi +720 £15.95 paperback.) Pennsylvania: Springhouse Corporation, 1990. Distributed by Harcourt Brace Jovanovich. ISBN 0-87434-218-X.

Inflammation and Drug Therapy Series. Vol 3. "New Developments in AntiVol 3. "New Developments in Antford, G P Velo. (Pp viii + 328; figs; ford, G P Velo. (Pp viii + 328; figs;
f40.) Dordrecht: Kluwer Academic, 440.) Dordrecht: Kluwer Academic,
1989. Distributed by MTP Press. 1989. Distributed
ISBN 0-7462-0080-3.

Modern Methods in Pharmacology. Vo 5. "Pharmacological Methods in the Control of Inflammation." Ed J Y Chang, A J Lewis. Series editors $S$ Spector, N Back. (Pp xv+505; figs \$98.) New York: Liss, 1989. Distributed by John Wiley and Sons. ISBN 0-471-51764-X.

Psychiatry

Contemporary Themes in Psychiatry: Tribute to Sir Martin Roth. Ed K Davison, A Kerr. (Pp xiii +519; figs: f20 paperback.) London: Gaskell, 1989. ISBN 0-902241-28-1

Dimensions of Psychoanalysis. Ed J Sandler. (Pp xv + 263; $£ 14.95$ paperback.) London: Karnac, 1989. ISBN 0-946439-74-5.

Freud and Man's Soul. B Bettelheim. Pp xii +112; $\{3.99$ paperback.) London: Penguin, 1989. ISBN 0-14 022872-1. 